\title{
Evolution of the mating types and mating strategies in prominent genera in the Botryosphaeriaceae
}

\author{
Jan H. Nagel ${ }^{1}$ \\ Michael J. Wingfield ${ }^{1}$ \\ Bernard Slippers ${ }^{1}$ \\ ${ }^{1}$ Department of Genetics, Forestry and Agricultural Biotechnology Institute (FABI), University \\ of Pretoria, Pretoria 0001 South Africa.
}

\begin{abstract}
:
Little is known regarding mating strategies in the Botryosphaeriaceae. To understand sexual reproduction in this fungal family, the mating type genes of Botryosphaeria dothidea and Macrophomina phaseolina, as well as several species of Diplodia, Lasiodiplodia and Neofusicoccum were characterized from whole genome assemblies. Comparisons between the mating type loci of these fungi showed that the mating type genes are highly variable, but in most cases the organization of these genes is conserved. Of the species considered, nine were homothallic and seven were heterothallic. Mating type gene fragments were discovered flanking the mating type regions, which indicates both ongoing and ancestral recombination occurring within the mating type region. Ancestral reconstruction analysis further indicated that heterothallism is the ancestral state in the Botryosphaeriaceae and this is supported by the presence of mating type gene fragments in homothallic species. The results also show that at least five transitions from heterothallism to homothallism have taken place in the Botryosphaeriaceae. The study provides a foundation for comparison of mating type evolution between Botryosphaeriaceae and other fungi and also provides valuable markers for population biology studies in this family.
\end{abstract} Keywords: Idiomorph, heterothallic, homothallic, ancestral state reconstruction, Dothideomycetes 


\section{Introduction}

Two modes of sexual reproduction exist in fungi, heterothallism and homothallism. In heterothallic fungi, two individuals of opposite mating compatibility types must be present in order for sexual reproduction to take place (Ni et al., 2011). Homothallism is characterized by indiscrimate mating, i.e. one fungal individual can mate with any other individual of its species, including itself. Both thallism states have advantages. Homothallism allows unrestricted sexual compatibility that is beneficial when the probability of encountering a mating partner is low and the benefits of occasional outcrossing outweigh the cost of more frequent haploid selfing. Conversely, heterothallism is better suited to situations where mating partners are encountered frequently, but the fitness cost for selfing is high (Billiard et al., 2012).

Ascomycetes have a bipolar mating system that is usually determined by a single locus (Butler, 2010). The ascomycete mating type genes occur at the MAT1 locus. In heterothallic fungi the genes are idiomorphic between the two mating types; that is the genes at the MAT1 locus are not homologous between the two mating types (Idnurm, 2011). The MAT1-1 idiomorph is defined as containing the MAT1-1-1 gene that possesses an alpha box protein domain (Turgeon and Yoder, 2000). Likewise the MAT1-2 idiomorph contains the MAT1-2-1 gene that produces a protein with the high mobility group (HMG) domain (Turgeon and Yoder, 2000).

The gene organization at the MAT1 locus, as well as the position of the locus in the genome is moderately conserved in the Ascomycota. The MAT1 locus may contain either the MAT11-1 or MAT1-2-1, alone or with one or more ancillary mating type genes. The naming of mating type genes follows the system described by Turgeon and Yoder (2000) and has recently been revised in order to correct inconsistent/incorrect application of the mating type gene nomenclature (Wilken et al., 2017). In many ascomycetes, the MAT1 locus is flanked by the SLA2 and APN2/DNA lyase genes (Debuchy and Turgeon, 2006). 
Homothallism can occur in various forms, i.e primary homothallism, pseudohomothallism and mating type switching (Wilson et al., 2015). Primary homothalism occurs when both mating type idiomorphs are present in one genome, either at the same locus (Pöggeler et al., 1997; Yun et al., 1999; Yun et al., 2000) or at unlinked loci (Galagan et al., 2005; Lopes et al., 2017). Additionally the MAT1-1-1 and MAT1-2-1 genes can be fused in a single functional gene that contains both the alpha-box and HMG domains (Yun et al., 1999).

The Botryosphaeriaceae is a family of fungi that commonly occur in woody plants as endophytes and many species are also important opportunisitic tree pathogens (Slippers and Wingfield, 2007). Sexual structures in these fungi are rarely observed in nature or under laboratory conditions (Phillips et al., 2013; Slippers et al., 2017). This, however, does not necessarily imply that species of Botryosphaeriaceae fail to undergo sexual reproduction. For example, physical evidence of sexual reproduction has never been observed for Diplodia sapinea, but most likely takes place when considering population genetics data (Bihon et al., 2012a; Bihon et al., 2012b). Consistent with this view, the mating type genes in $D$. sapinea were subsequently characterized and these showed that the fungus is heterothallic (Bihon et al., 2014). The MAT1-1 idiomorph of D. sapinea contains the MAT1-1-1 gene, as well as the MAT1-1-8 gene, whereas the MAT1-2 idiomorph contains the MAT1-2-1 genes, as well as a novel MAT1-2-5 gene. Bihon et al. (2014) further showed that all but one of the populations considered did not deviate significantly deviate from the $1: 1$ ratio between the two mating type idiomorphs, further supporting sexual reproduction in this species.

The mating type genes in several other Botryosphaeriales have recently been characterized (Amorim et al., 2017; Lopes et al., 2017; Marsberg et al., 2016; Wang et al., 2016). A genome assembly for Neofusicoccum parvum was used to identify the mating type genes of this species and revealed both MAT1-1 and MAT1-2 idiomorphs in the genome, indicating primary homothallism (Lopes et al., 2017). Primer sets that allowed amplification of the 
MAT1-1-1 and MAT1-2-1 genes from other species in this genus were also developed (Lopes et al., 2017). Similarly, a genome assembly was used to characterize the mating type genes of Botryosphaeria dothidea, which was shown to be homothallic (Marsberg et al., 2016). The mating type locus in Phyllosticta citricarpa (Phyllostictaceae) (Amorim et al., 2017; Wang et al., 2016) and P. capitalensis (Wang et al., 2016) has also been characterized using a similar genomics based approach, showing that $P$. citricarpa is heterothallic and $P$. capitalensis is homothallic.

Recent studies on the mating type genes in species of Botryosphaeriales have highlighted various knowledge gaps regarding sexual reproduction in these fungi. For example, questions arise regarding the conservation of mating types, i.e. the conservation of nucleotide and amino acid sequence of the mating type genes, the conservation of the genes occurring at the mating type locus and the conservation of the genomic location of the mating type locus. It is also not known how thallism has evolved in this family; whether the most recent common ancestor of the Botryosphaeriaceae was homothallic or heterothallic or how frequently changes to the ancestral mating strategy have evolved. Furthermore, a scarcity of mating type markers capable of amplifying a broad range of species, other than those for Neofusicoccum spp. developed by Lopes et al. (2017), limits our capacity to investigate thallism and mating type ratios in Botryosphaeriaceae species, for which genomic data are not available.

Knowledge regarding the mating types and mode of reproduction is lacking for some of the most commonly occurring genera in the Botryosphaeriaceae. Consequently, the aim of this study was to characterize the mating type loci of several species of the Botryosphaeriaceae using both publicly available genomic data and genomic assemblies determined as part of this study. The architecture of these mating type loci and their flanking genes were compared and their phylogenetic relationships analysed to reconstruct the evolutionary 
history of mating strategies in this family. A set of primers was also designed to facilitate future studies of mating systems in the Botryosphaeriaceae.

\section{Materials and Methods}

\subsection{Acquisition of genome sequences}

Genomic sequence data used in analyses were acquired either from incomplete de novo genome assemblies or from public genomic databases (Table 1). The incomplete de novo genome sequencing was performed using paired-end reads on a Illumina Hiseq 2500 platform. Sequencing reads were trimmed using Trimmomatic 0.36 (Bolger et al., 2014) and assembled with Velvet (Zerbino and Birney, 2008) and Velvetoptimiser (Gladman and Seemann, 2012).

\subsection{Characterization of mating type and surrounding genes}

The presence of mating type genes from the genome sequences was determined by performing a local tBLASTx (Camacho et al., 2009) search using the MAT and adjacent genes from D. sapinea (KF551229 and KF551228) (Bihon et al., 2014). The relevant contigs were extracted from genome sequences and annotated using WebAugustus (http:// bioinf.uni-greifswald.de/augustus/). The identities of the annotated genes were determined by BLASTp against the NCBI nr-database. The annotations were further manually refined by comparison with existing homologs on NCBI. The resultant annotated loci of sequence data generated in this study were deposited in GenBank (Table 1). The mating type gene annotations from publically available genome data are provided in Supplementary File 1. Mating type genes were assessed for functional domains by performing a search against NCBl's conserved domain database (CDD BLAST) (Marchler-Bauer et al., 2014). 
Table 1. Data on genome sequences used in this study including details of mating type and thallism.

\begin{tabular}{|c|c|c|c|c|c|c|c|}
\hline \multirow[t]{2}{*}{ Species } & \multirow{2}{*}{$\begin{array}{l}\text { Reference } \\
\text { collection } \\
\text { number* }\end{array}$} & \multirow{2}{*}{$\begin{array}{c}\text { Other } \\
\text { collection } \\
\text { numbers or } \\
\text { strain }\end{array}$} & \multirow[t]{2}{*}{ Thallism } & \multirow{3}{*}{$\begin{array}{l}\text { Mating } \\
\text { type }\end{array}$} & \multicolumn{3}{|c|}{ Accession Numbers } \\
\hline & & & & & MIAI IOcus & Genome & Genome reference \\
\hline Botryosphaeria dothidea & & LW030101 & Homothallic & & & MDSR00000000 & (Liu et al., 2016) \\
\hline Diplodia corticola & CBS112549 & & Heterothallic & MAT1-1 & & MNUE01000001 & \\
\hline \multirow[t]{2}{*}{ D. sapinea } & CBS117911 & CMW190 & \multirow{2}{*}{ Heterothallic } & MAT1-1 & KF551229 & AXCF00000000 & \multirow{2}{*}{ (van der Nest et al., 2014) } \\
\hline & CBS138184 & CMW39103 & & MAT1-2 & KF551228 & JHUM00000000 & \\
\hline \multirow[t]{3}{*}{ D. seriata } & & F98.1 & & MAT1-1 & & MSZU00000000 & (Robert-Siegwald et al., 2017) \\
\hline & & UCDDS831 & Heterothallic & MAT1-2 & & LAQI00000000 & (Morales-Cruz et al., 2015) \\
\hline & CBS112555 & CMW 31769 & & MAT1-2 & KX787890 & & \\
\hline D.scrobiculata & CBS139796 & CMW30223 & Heterothallic & MAT1-1 & & LAEG00000000 & (Wingfield et al., 2015) \\
\hline Lasiodiplodia gonubiensis & CBS115812 & CMW 14077 & Homothallic & & KX787887 & & \\
\hline L. pseudotheobromae & CBS116459 & CMW 31774 & Heterothallic & MAT1-1 & KX787888 & & \\
\hline \multirow[t]{2}{*}{ L. theobromae } & CBS164.96 & CMW40942 & \multirow{2}{*}{ Heterothallic } & MAT1-1 & KX787889 & & \\
\hline & & CSS001 & & MAT1-2 & & MDYX00000000 & (Yan et al., 2017) \\
\hline \multirow[t]{2}{*}{ Macrophomina phaseolina } & & MS6 & \multirow{2}{*}{ Heterothallic } & MAT1-1 & & AHHD00000000 & (Islam et al., 2012) \\
\hline & & MP00003 & & MAT1-2 & & LHTM00000000 & \\
\hline Neofusicoccum australe & & CMW 6837 & Homothallic & & KY775140 KY775142 & & \\
\hline \multirow[t]{2}{*}{ N. cordaticola } & CBS123634 & CMW13992 & \multirow{2}{*}{ Homothallic } & & KY612503 KY612506 & & \\
\hline & CBS123638 & CMW14124 & & & KX766040 KX766043 & & \\
\hline \multirow[t]{2}{*}{ N. kwambonambiense } & CBS123639 & CMW14023 & \multirow{2}{*}{ Homothallic } & & KY612505 KY612507 & & \\
\hline & CBS123642 & CMW14155 & & & KX766039 KX766045 & & \\
\hline N. luteum & & CMW 9076 & Homothallic & & KY775141 KY775143 & & \\
\hline \multirow[t]{4}{*}{ N. parvum } & & UCRNP2 & \multirow{4}{*}{ Homothallic } & & KB915846 KB916244 & AORE 00000000 & (Blanco-Ulate et al., 2013) \\
\hline & & UCD646So & & & & PRJNA321421 & (Massonnet et al., 2016) \\
\hline & & CMW9080 & & & KY612501 KY612508 & & \\
\hline & CBS123649 & CMW14085 & & & KX766038 KX766044 & & \\
\hline N. ribis & CBS115475 & CMW7772 & Homothallic & & KY612504 KY612509 & & \\
\hline
\end{tabular}




\begin{tabular}{|c|c|c|c|c|}
\hline \multirow{3}{*}{ N. umdonicola } & CBS121.26 & CMW7054 & & KX766036 KX766041 \\
\hline & CBS123645 & CMW14058 & \multirow{2}{*}{ Homothallic } & KY612502 KY612510 \\
\hline & CBS123644 & CMW14106 & & KX766037 KX766042 \\
\hline
\end{tabular}

* Entries in boldface represents isolates where mating type sequences were obtained from incomplete genomes in the present study 


\subsection{Comparison of mating type locus organization}

In order to compare the organization of the mating type genes and flanking genes between species, BLASTn was used to assess the similarity between sequences. EasyFig version 2.2.2 (Sullivan et al., 2011) was used to perform synteny analysis based on pairwise BLASTn similarity between taxa using a maximum E-value cut-off of 0.0001 . This approach was also used to assess the presence of partial MAT gene fragments at the mating type locus. Intergenic regions on either side of the mating type genes were investigated for the presence of sequences with homology to the MAT1-1-1, MAT1-1-8, MAT1-2-1 or MAT1-2-5 genes. Where only a single mating type was available for a species (i.e $D$. corticola, $D$. scrobiculata and L. pseudotheobromea), the genes of the opposite mating type from the closest available species was used to determine the presence of mating type gene fragments in the intergenic regions flanking the mating type genes.

\subsection{Phylogenetic comparisons and ancestral state reconstruction}

Phylogenetic analyses of the MAT1-1-1 and MAT1-2-1 genes were performed using the nucleotide sequence data of the protein coding regions. Sequences were aligned using MAFFT version 7 (Katoh and Standley, 2013). RAxML (Stamatakis, 2014) was used to generate Maximum Likelihood phylogenetic trees using a GTRCATI model and a thousand bootstrap replicates to assess branch support. Additionally, Bayesian statistical inference was also applied to generate phylogenetic trees and posterior probability node support for the mating type genes. Each gene alignment was subjected to hierarchical Likelihood ratio tests using MrModeltest2.2 (Nylander 2004). Bayesian analysis was performed for one million generations on MrBayes version 3.1 (Ronquist and Huelsenbeck, 2003). The burn-in was determined using Tracer (Rambaut and Drummond, 2003), prior to tree and parameter summarization.

Reconstruction of the ancestral thallic state was performed using Mesquite 3.10 (Maddison and Maddison, 2016). The topology of the multi-gene phylogenetic tree of Slippers et al. (2013) was used as a backbone to map characters. The character states mapped onto the 
phylogenetic backbone were heterothallism, homothallism or unknown. Species were designated as heterothallic when a single mating type (either MAT1-1 or MAT1-2) was present in the genome. Conversely, homothallic species were identified by the presence of both mating types in a single genome. Character state data used in this analysis included those generated in the current study, as well as previous studies of the Botryosphaeriales (Lopes et al., 2017; Wang et al., 2016). An unordered parsimony model was used to map character states onto the tree and to reconstruct ancestral states.

\subsection{Primer design and PCR amplification}

Primers for amplification of the primary mating type genes have previously been designed for D. sapinea (Bihon et al., 2014) and Neofusicoccum spp. (Lopes et al., 2017). The MAT1-1-1 and MAT1-2-1 gene sequences of the Lasiodiplodia spp. and $B$. dothidea were used to design primers for each genus, respectively (Table 2). Additionally, the MAT1-1-1 gene was used to design primers for amplification in the other Diplodia species, but not for the MAT12-1 gene. This was because the existing primers (DipHMG) were able to amplify in $D$. seriata, which is the only other MAT1-2 isolate with sequence data available for that genus. Primer3 (Rozen and Skaletsky, 1999) was used to determine optimal primer location. For the MAT1-1-1 primers, the three Lasiodiplodia spp. were aligned and primers were designed at conserved regions so as to potentially amplify across many species in the genus. For the MAT1-2-1 primers, sequences of $L$. gonubiensis and $L$. theobromae were aligned and primers were designed at conserved regions. The same approach was used for the Diplodia MAT1-1-1 primers using sequences of $D$. sapinea, $D$. scrobiculata and $D$. corticola. Separate primer pairs were designed to amplify both the MAT1-1-1 and MAT1-2-1 genes from $B$. dothidea.

Template DNA for polymerase chain reactions (PCRs) was extracted using the protocol described by Möller et al. (1992). PCRs were set up as follows: 1 x PCR reaction buffer, 2 $\mathrm{mM} \mathrm{MgCl} 2,200 \mu \mathrm{M}$ of each dNTP, $0.4 \mu \mathrm{M}$ of each primer, $1 \mathrm{U}$ of FastStart Taq Polymerase 
Table 2. Primer pairs for amplification of mating type gene fragments

\begin{tabular}{|c|c|c|c|c|}
\hline Primer Name & Sequence & $\operatorname{Tm}(\mathrm{C})$ & $\begin{array}{l}\text { Fragment } \\
\text { size }\end{array}$ & Species with successful amplification \\
\hline Botryosphaeria dothidea MAT1-1-1 & & & 820 bp & Botryosphaeria dothidea (CMW8000) \\
\hline BdM1f & GACTCGTCCACCTCACTTCA & 63.5 & & \\
\hline BdM1r & CAGAGTAGTGGTGCCAGAGG & 63.0 & & \\
\hline Botryosphaeria dothidea MAT1-2-1 & & & $444 \mathrm{bp}$ & Botryosphaeria dothidea (CMW8000) \\
\hline $\mathrm{BdM} 2 \mathrm{f}$ & GACCGCAGAGATCAAGAAGC & 64.5 & & \\
\hline $\mathrm{BdM} 2 \mathrm{r}$ & TCAGCGAGAAGGCCATAGTT & 64.2 & & \\
\hline Diplodia MAT1-1-1 & & & $750-870 \mathrm{bp}$ & Diplodia sapinea (CBS117911) \\
\hline DipM1f3 & AGCTCATCCGTCGCTTCATTC & 68 & & D. scrobiculata (CBS139796) \\
\hline DipMr3 & CGGTGCATGTCGAATGC & 65.8 & & D. corticola (CMW38070) \\
\hline Lasiodiplodia MAT1-1-1 & & & $820-850 \mathrm{bp}$ & Lasiodiplodia theobromae (CBS164.96) \\
\hline LasM1f & AACTGCTTCGTTGCCTTCC & 64.7 & & L. pseudotheobromae (CBS116459) \\
\hline \multirow[t]{3}{*}{ LasM1r2 } & AGACAGGTCAGGGTCAATGG & 64.5 & & L. gonubiensis (CBS115812) \\
\hline & & & & L. citricola (CMW37047) \\
\hline & & & & L. iraniensis (CMW37051) \\
\hline Lasiodiplodia MAT1-2-1 & & & $711 \mathrm{bp}$ & L. theobromae (CMW32498) \\
\hline LasM2f1 & ACCGCAGGGACAACCAC & 65.4 & & L. gonubiensis (CBS115812) \\
\hline \multirow[t]{5}{*}{ LasM2r1 } & GTTGCGCTGGGAAGCAG & 66.4 & & L. gilanensis (CMW37048) \\
\hline & & & & L. mediterranea (CMW43392) \\
\hline & & & & L. lignicola (CMW40932) \\
\hline & & & & D. scrobiculata (CBS118110) \\
\hline & & & & D. seriata (CBS112555) \\
\hline
\end{tabular}


(Roche) and PCR grade water to the final reaction volume of $25 \mu \mathrm{l}$. Between 2 and $20 \mathrm{ng}$ of gDNA was used as template for PCR. Thermocycling was performed on a Veriti Thermal Cycler (Applied Biosystems) using an initial step of $95 \mathrm{C}$ for five minutes, followed by 35 cycles of $95 \mathrm{C}$ for $30 \mathrm{~s}, 58 \mathrm{C}$ for $45 \mathrm{~s}, 72 \mathrm{C}$ for $60 \mathrm{~s}$, and a final extention step of $72 \mathrm{C}$ for 4 min. Resultant amplicons were sequenced using the same primers as those used in PCR.

\section{Results}

\subsection{Mating type genes of Botryosphaeriaceae}

Genes showing strong homology to the mating type genes of $D$. sapinea were identified from 28 Botryosphaeriaceae genomes, 16 of which were from incomplete genome sequences generated in this study. The genes of each mating type idiomorph (MAT1-1 and MAT1-2) always co-occurred in the genomes, i.e MAT1-1-1 and MAT1-1-8 always cooccured, MAT1- 2-1 and MAT1-2-5 always co-occurred. The MAT1-1-1 and MAT1-2-1 genes had strong homology to conserved protein domains based on CDD BLAST (Table 3). The MAT1-1-1 genes all contained the MATalpha (pfam04769) domain and the MAT1-2-1 genes all contained the MAT_HMG-box (cd01389) domain.

Based on the presence of the mating type genes identified in each genome, species could be designated as either heterothallic or homothallic. Botryosphaeria dothidea, L. gonubiense, as well as all species of Neofusicoccum examined were homothallic with the genomes containing both the MAT1-1 and MAT1-2 idiomorphs. Diplodia corticola, D. scrobiculata, D. seriata, L. theobromea, L. pseudotheobromea and M. phaseolina were identified as heterothallic. Of the heterothallic species with only a single representative genome, all were of isolates possessing the MAT1-1 idiomorph.

The nucleotide and amino acid sequence conservation of the mating type genes was considerably lower than that of the adjacent genes (Table 4). The size of the coding sequences for the mating type genes, as well as the size and location of the introns was 


\begin{tabular}{|c|c|c|c|c|}
\hline \multirow[t]{2}{*}{ Species } & \multirow[t]{2}{*}{ Gene } & \multicolumn{2}{|c|}{ Amino acid Interval } & \multirow[b]{2}{*}{ E value } \\
\hline & & MATalpha & MAT_HMG-box & \\
\hline \multirow[t]{2}{*}{ Botryosphaeria dothidea } & MAT1-1-1 & $31-160$ & & 4.19E-38 \\
\hline & MAT1-2-1 & & $174-248$ & $2.55 \mathrm{E}-29$ \\
\hline Diplodia scrobiculata & MAT1-1-1 & $63-205$ & & 5.09E-41 \\
\hline D. corticola & MAT1-1-1 & $87-223$ & & $1.84 \mathrm{E}-36$ \\
\hline \multirow[t]{2}{*}{ D. sapinea } & MAT1-1-1 & $40-210$ & & 5.50E-41 \\
\hline & MAT1-2-1 & & $130-206$ & 4.09E-38 \\
\hline \multirow[t]{2}{*}{ D. seriata } & MAT1-1-1 & $48-210$ & & 8.19E-43 \\
\hline & MAT1-2-1 & & $129-205$ & 1.89E-33 \\
\hline \multirow[t]{2}{*}{ Lasiodiplodia gonubiensis } & MAT1-1-1 & $80-198$ & & 1.17E-37 \\
\hline & MAT1-2-1 & & $180-253$ & $5.92 E-32$ \\
\hline \multirow[t]{2}{*}{ L. theobromae } & MAT1-1-1 & $71-201$ & & 5.26E-39 \\
\hline & MAT1-2-1 & & $191-260$ & $2.18 \mathrm{E}-25$ \\
\hline L. pseudotheobromae & MAT1-1-1 & $72-196$ & & 4.70E-39 \\
\hline \multirow[t]{2}{*}{ Macrophomina phaseolina } & MAT1-1-1 & $49-199$ & & $7.14 \mathrm{E}-38$ \\
\hline & MAT1-2-1 & & $190-264$ & $3.23 E-26$ \\
\hline \multirow[t]{2}{*}{ Neofusicoccum australe } & MAT1-1-1 & $32-207$ & & $5.01 \mathrm{E}-40$ \\
\hline & MAT1-2-1 & & $181-255$ & $6.11 \mathrm{E}-35$ \\
\hline \multirow[t]{2}{*}{ N. cordaticola } & MAT1-1-1 & $31-207$ & & 8.84E-42 \\
\hline & MAT1-2-1 & & $221-295$ & $5.76 \mathrm{E}-36$ \\
\hline \multirow[t]{2}{*}{ N. kwambonambiense } & MAT1-1-1 & $31-210$ & & $6.99 \mathrm{E}-41$ \\
\hline & MAT1-2-1 & & 221-295 & 7.01E-36 \\
\hline \multirow[t]{2}{*}{ N. luteum } & MAT1-1-1 & $32-207$ & & $9.14 \mathrm{E}-40$ \\
\hline & MAT1-2-1 & & $181-255$ & 6.17E-35 \\
\hline \multirow[t]{2}{*}{ N. parvum } & MAT1-1-1 & $31-207$ & & $6.85 E-42$ \\
\hline & MAT1-2-1 & & $221-295$ & $1.55 \mathrm{E}-35$ \\
\hline \multirow[t]{2}{*}{ N. ribis } & MAT1-1-1 & $31-207$ & & 5.63E-41 \\
\hline & MAT1-2-1 & & $221-295$ & $7.53 E-36$ \\
\hline N. umdonicola & MAT1-1-1 & $31-217$ & & 1.35E-41 \\
\hline
\end{tabular}


Table 4. Nucleotide and amino acid conservation of mating type genes of species of Botryosphaeriaceae

\begin{tabular}{|l|c|c|c|c|}
\hline \multicolumn{1}{|c|}{ Gene } & $\begin{array}{c}\text { Nucleotide } \\
\text { conservation* }\end{array}$ & $\%$ & $\begin{array}{c}\text { Amino acid } \\
\text { conservation* }\end{array}$ & $\%$ \\
\hline MAT1-1-1 & $313 / 1167$ & 26.82 & $93 / 388$ & 23.97 \\
\hline MAT1-1-8 & $209 / 933$ & 22.40 & $47 / 232$ & 20.26 \\
\hline MAT1-2-1 & $217 / 942$ & 23.04 & $51 / 313$ & 16.29 \\
\hline MAT1-2-5 & $166 / 783$ & 21.20 & $42 / 248$ & 16.94 \\
\hline APN2 & $936 / 1881$ & 49.76 & $363 / 629$ & 57.71 \\
\hline CIA30 & $398 / 642$ & 61.99 & $160 / 214$ & 74.77 \\
\hline CoxVIa & $286 / 384$ & 74.48 & $90 / 127$ & 70.87 \\
\hline APC5 & $798 / 1398$ & 57.08 & $308 / 478$ & 64.44 \\
\hline MCP & $541 / 834$ & 64.87 & $236 / 277$ & 85.20 \\
\hline SAICARsyn & $577 / 1957$ & 29.48 & $222 / 318$ & 69.81 \\
\hline *Identity at sites not containing any gaps in the alignment \\
\hline
\end{tabular}

\section{Highlights}

- The mating type loci of several species of Botryosphaeriaceae were characterized

- Heterothallism appears to be the ancestral state in Botryosphaeriaceae

- Multiple shifts from heterothallism to homothallism have occured in this family

- Mating type markers for select Botryosphaeriaceae were developed 
generally conserved (Supplementary File 3). There were, however, some exceptions. The MAT1-1-1 gene of M. phaseolina contained an intron more than double the length of those in other species; the MAT1-1-8 gene of $B$. dothidea was significantly longer than that of other Botryosphaeriaceae; the MAT1-2-1 gene of both $D$. sapinea and D. seriata contained a single intron, compared to the two in the other Botryosphaeriaceae.

\subsection{Organization of mating type loci}

Three types of gene arrangements were observed at the mating type locus. In most species (Figure 1), the mating type genes occurred between a syntenic cluster of six genes and a gene with a putative integral membrane $(P I M)$ protein (also referred to as Pleckstrin homology domain containing protein and DUF2404), similar to that described by Bihon et al. (2014). The syntenic cluster consisted of six genes with a conserved order and orientation. These six genes were all protein coding and are as follows: DNA lyase (APN2), Cytochrome c oxidase subunit Vla (CoxVla), Anaphase-promoting complex subunit 5 (APC5), Complex I intermediate-associated protein 30 (CIA30), Mitochondrial carrier

protein $\quad(M C P), \quad$ Phosphoribosylaminoimidazolesuccinocarboxamide Synthetase (SAICARsyn).

A second organization (Supplementary File 2), seen only in the Neofusicoccum parvum/N. ribis complex (N. cordaticola, N. kwambomambiense, $N$. parvum, $N$. ribis and $N$. umdonicola), was similar to that described by Lopes et al. (2017) where the MAT1-1 and MAT1-2 genes occur at separate genomic loci and neither occurring in close proximity to the syntenic cluster that flanks the mating type genes in the other genera of Botryosphaeriaceae. However, investigation of these genes in the N. parvum UCD646So genome (Massonnet et al., 2016) indicated that the MAT1-1 mating type is located on the same chromosome (contig 3 from Massonnet et al. (2016)) as the APN2-SAICARsyn cluster, but $242 \mathrm{~kb}$ distant from it. Furthermore, the MAT1-2 mating type occurred on a separate chromosome (contig 36 from Massonnet et al. (2016)) very close (12kb) to the telomere. 


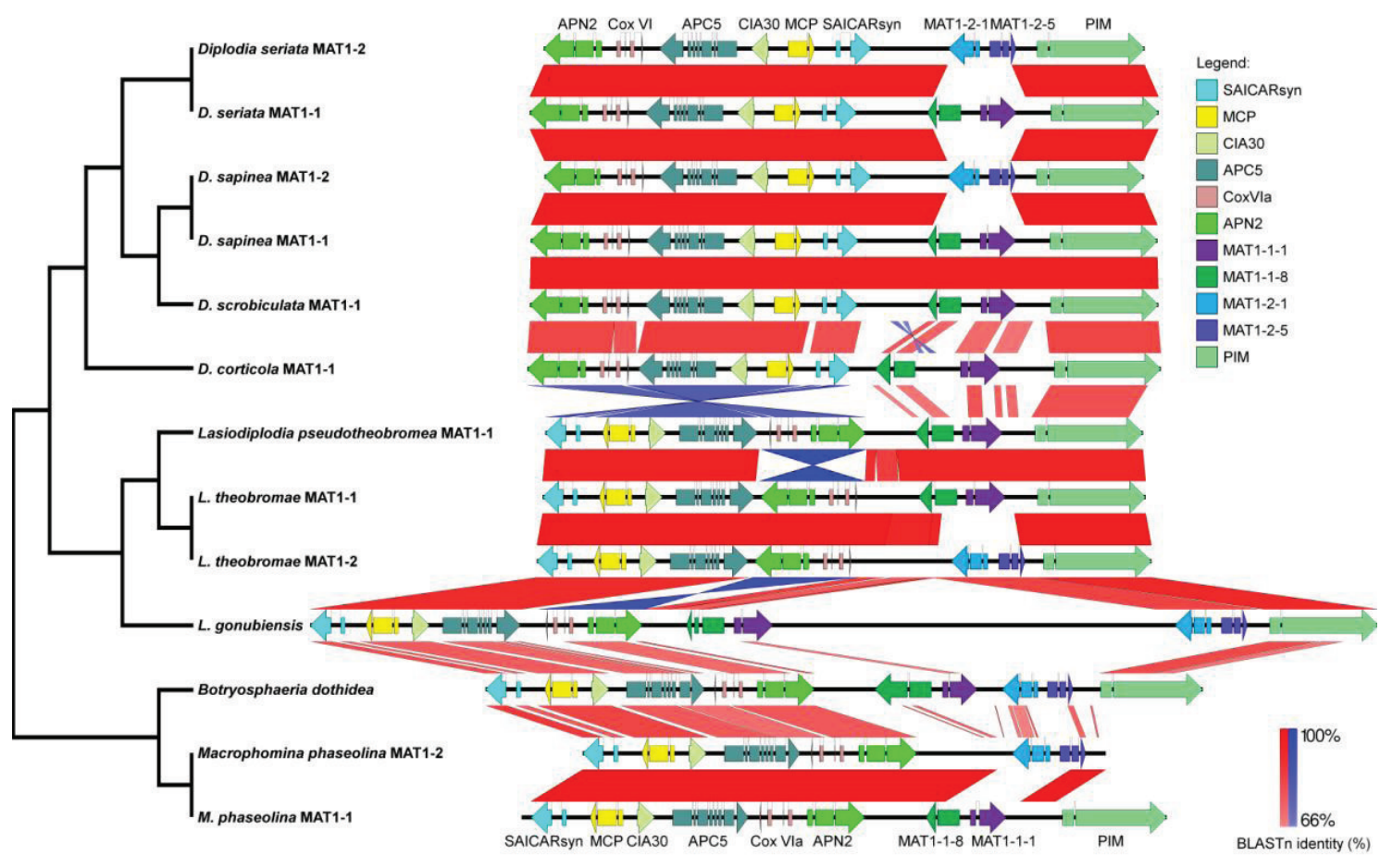

Fig. 1. Pairwise mating type locus comparison between species of Botryosphaeriaceae (excluding Neofusicoccum spp.). Black horizontal lines represent genomic sequences, annotated with colour coded arrows representing genes. Red and blue boxes between genomic sequences indicates pair wise similarity based on BLASTn, red boxes indicate that both regions are in the same orientation and blue boxes indicate that regions are orientated in opposite directions. Genes are abbreviated as follows: DNA lyase (APN2), Cytochrome c oxidase subunit Via (Cox-Via), Anaphase-promoting complex subunit 5 $(A P C 5)$, Complex I intermediate-associated protein 30 (CIA30), Mitochondrial carrier protein (MCP), Phosphoribosylaminoimidazolesuccinocarboxamide Synthetase (SAICARsyn), Putative integral membrane protein $(P I M)$. The relationships between taxa are indicated by the cladogram on the left. 
The third type of gene arrangement (Supplementary File 2) was observed in N. australe and $N$. luteum where the MAT1-2 idiomorph occurred directly downstream of the APN2SAICARsyn cluster. The MAT1-1 idiomorph occurred on a separate contig flanked on one side by phosphoglucomutase and beta-glycosidase genes. The proximity of the two mating types could not be determined in N. australe and N. luteum.

The orientation of the mating type genes was well conserved in all species of Botryosphaeriaceae. We orientated the mating type locus by the direction of the MAT1-1-1 gene. The two genes of each idiomorph (MAT1-1-1 and MAT1-1-8, and MAT1-2-1 and MAT1-2-5) were always arranged in opposite directions. Furthermore, the MAT1-2-1 gene was always orientated in the opposite direction as the MAT1-1-1 gene.

Although the orientation of the mating type idiomorphs was conserved in the species of Botryosphaeriaceae considered, several rearrangements were observed (Figure 1). In all the Diplodia species, the syntenic cluster preceding the mating type locus was in the APN2 to SAICARsyn orientation, as described by Bihon et al. (2014). In most other species of Botryosphaeriaceae, these six genes were in the opposite orientation with APN2 being the most proximal to the MAT genes. In N. parvum, the APN2-SAICARsyn cluster also occurred in the same orientation to the MAT1-1 idiomorph, similar to the situation in Diplodia, although it was not directly adjacent to it. In L. theobromae, the position and orientation of APN2 and CoxVla was inverted.

Both L. gonubiensis and B. dothidea had both the MAT1-1 and MAT1-2 idiomorphs at the same locus (Figure 1) and were, therefore, considered homothallic. In both these species, the MAT1-1 and MAT1-2 idiomorphs occurred adjacent to one another, with the MAT1-1 idiomorph preceding the MAT1-2 idiomorph. Lasiodiplodia gonubiensis had a very large $(\sim 15 \mathrm{~kb})$ intergenic region between the genes of the two idiomorphs. This intergenic region consisted of low complexity, A-T rich sequence. 
With the exception of the genes flanking the MAT1-2 idiomorph, the mating type idiomorph organization of the four additional species in the Neofusicoccum parvum/N. ribis complex was identical to that previously found in Neofusicoccum parvum (Lopes et al., 2017). The MAT1-1 idiomorphs occurred between the AMP-binding protein and major facilitator superfamily (MFS) allantoate encoding genes. The MAT1-2 idiomorphs were flanked on one side either by a putative mutator element gene (N. parvum), a DNA helicase gene $(N$. ribis and $N$. umdonicola) or a retrotransposon gag protein $(N$. cordaticola). The MAT1-2 idiomorphs were flanked on the other side by the PIM gene followed by a putative cutinase gene. No genes resembling the mating type genes were present adjacent to the APN2-SAICARsyn syntenic cluster in the species of the Neofusicoccum parvum/N. ribis complex, but were rather followed by an F-box protein.

\subsection{Mating type gene fragments}

Sequences with homology to either the MAT1-1-8 or MAT1-2-5 genes were observed in the intergenic regions flanking the mating types genes of most species considered in this study (Figure 2). All heterothallic species of Botryosphaeriaceae had sequences with homology to the 3' end of the MAT1-2-5 gene in the 3' intergenic region of the MAT1-1 idiomorph. Furthermore, all heterothallic species had sequences with homology to the 3 ' end of the MAT1-1-8 gene in the $5^{\prime}$ intergenic region of the MAT1-2 idiomorph (Figure 2). Despite the strong homology to the MAT1-1-8 and MAT1-2-5 genes, these sequences did not code for any proteins or contain open reading frames as no start codon was present.

Sequences with homology to mating type genes also occured in homothallic species of Botryosphaeriaceae. In L. gonubiensis, the sequence upstream of the MAT1-2-1 gene had homology to the middle region of its MAT1-1-8 gene. In contrast, $B$. dothidea, had no such homologous sequences in the intergenic region surrounding its mating type genes. In the five species residing in the Neofusicoccum parvum/N. ribis complex, the 3' intergenic 
Diplodia corticola

MAT1-1

D. seriata

MAT1-1

D. scrobiculata

MAT1-1

D. sapinea

MAT1-1

D. sapinea

MAT1-2

D. seriata

MAT1-2

Lasiodiplodia gonubiensis

MAT1-1 segment

L. pseudotheobromae

MAT1-1

L. theobromae

MAT1-1

L. theobromae

MAT1-2

L. gonubiensis

MAT1-2 segment
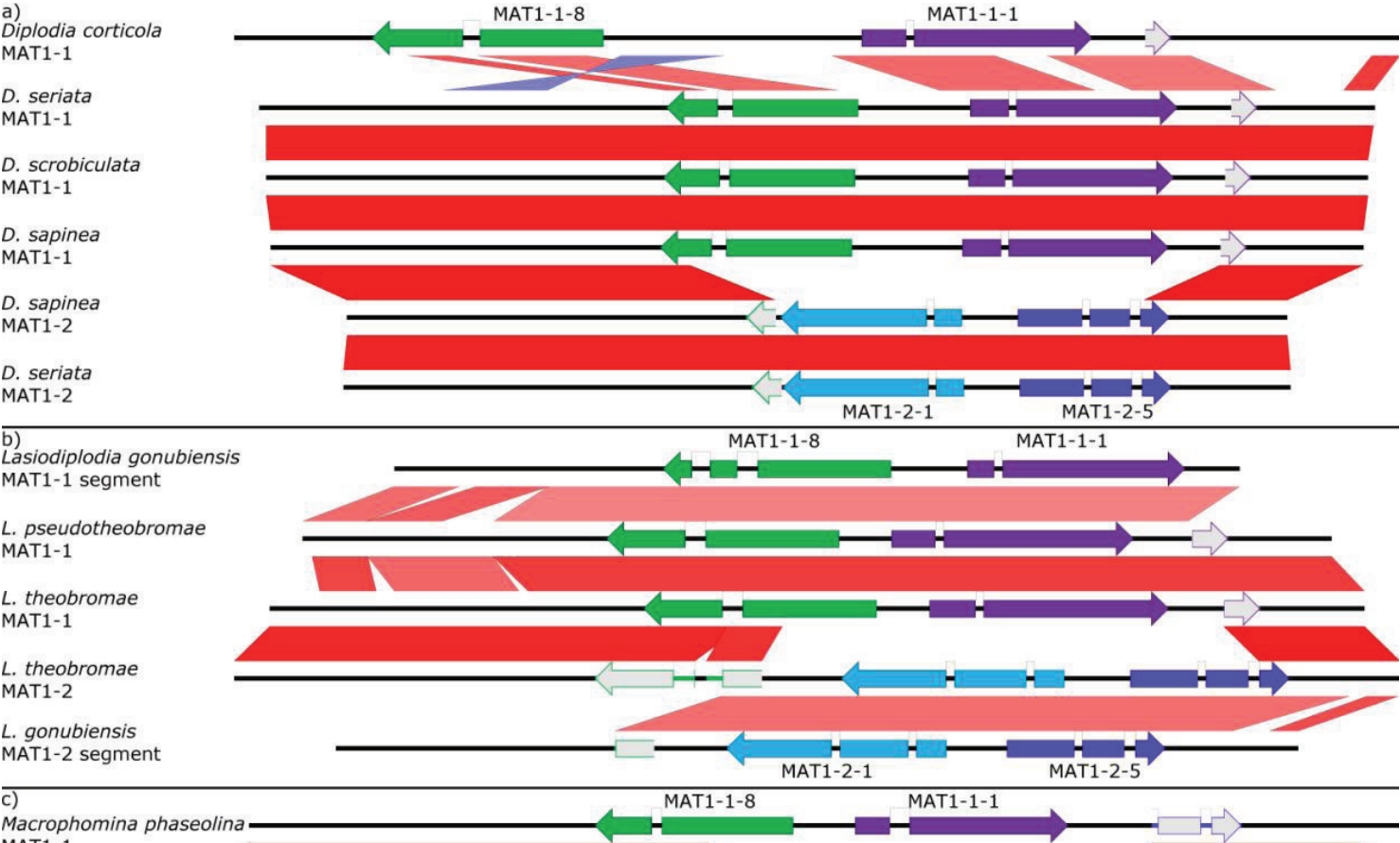

MAT1-1

M. phaseolina MAT1-2

d)

MAT1-1 locus

N. parvum MAT1-2 locus

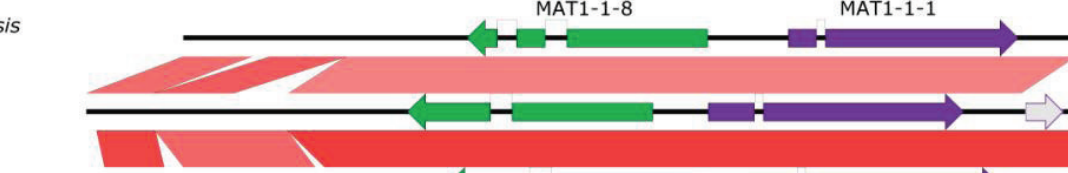

MAT1-2-1 MAT1-2-5

e) MAT1-1-8 MAT1-1-1

N. luteum MAT1-1 locus

N. Iuteum MAT1-2 locus

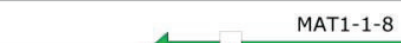

MAT1-1-8

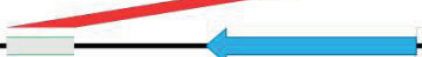

MAT1-2-1

MAT1-2-5

Fig. 2. Comparison of mating type loci to indicate intergenic regions with homology to the mating type genes of the opposite idiomorph. Comparison of mating type sequences of (a) Diplodia spp.,

(b) Lasiodiplodia spp., (c) Macrophomina phaseolina, (d) Neofusicoccum parvum and (e) N. luteum. Black horizontal lines represent genomic sequences, annotated with colour coded arrows representing genes.

Red and blue boxes between genomic sequences indicates pair wise similarity based on BLASTn, red boxes indicate that both regions are in the same orientation and blue boxes indicate that regions are orientated in opposite directions. Light grey arrows indicate truncated gene sequences. 
sequences of the MAT1-1 idiomorph had homology to the middle of the MAT1-2-5 gene (Figure 2d, only $N$. parvum shown). In $N$. australe and $N$. luteum the 5 ' intergenic region of the MAT1-2 idiomorph contained sequence homologous to the middle of the MAT1-1-8 gene (Figure 2e, N. luteum illustrated).

\subsection{Phylogeny of mating type genes and ancestral reconstruction of thallism}

Both maximum likelihood and Bayesian inference yielded phylogenetic trees with identical topologies for both the MAT1-1-1 and MAT1-2-1 genes. Consequently, the bootstrap and posterior probability support values were combined on a single tree for each gene (Figure 3). The phylograms for these genes had similar topologies with strong support for the major clades, corresponding to the different genera used in this study.

The ancestral reconstruction analysis (Figure 4) traced the character history onto the phylogenetic tree and suggested that heterothallism is the ancestral state in this family. Six character state changes occurred across this phylogeny, including one state change in the outgroup (Phyllostictaceae) lineage. Five independent transitions from heterothallism to homothallism were observed in the Botryosphaeriaceae. No transition from homothallism to heterothallism was observed.

\subsection{Mating type primers and amplification}

Primers could successfully amplify MAT1-1-1/MAT1-2-1 gene fragments in the species for which they were designed, as well as for some additional species indicated in Table 2. Primers were not designed for Neofusicoccum spp. because these were already available from the study of Lopes et al., (2017).

\section{Discussion}

This study characterized mating type genes in sixteen species residing in five genera of the Botryosphaeriaceae. The gene content and order within the MAT1-1 and MAT1-2 


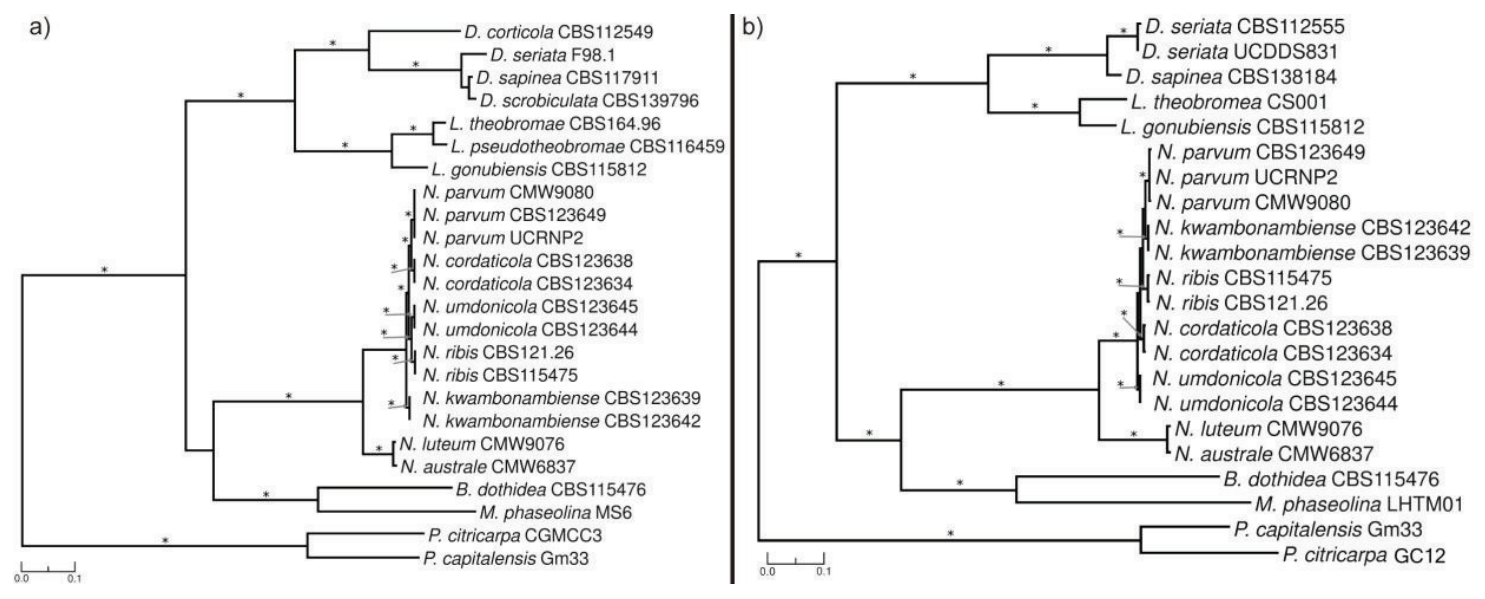

Fig. 3. Maximum likelihood phylogenetic tree of the (a) MAT1-1-1 and (b) MAT1-2-1 genes from species of Botryosphaeriaceae. Branches with bootstrap support higher than $85 \%$ and Bayesian inference posterior probabilities higher than 0.95 are indicated using an asterisk $\left(^{*}\right)$ symbol. Both phylogenetic trees are rooted using Phyllosticta citricarpa and P. capitalensis. 


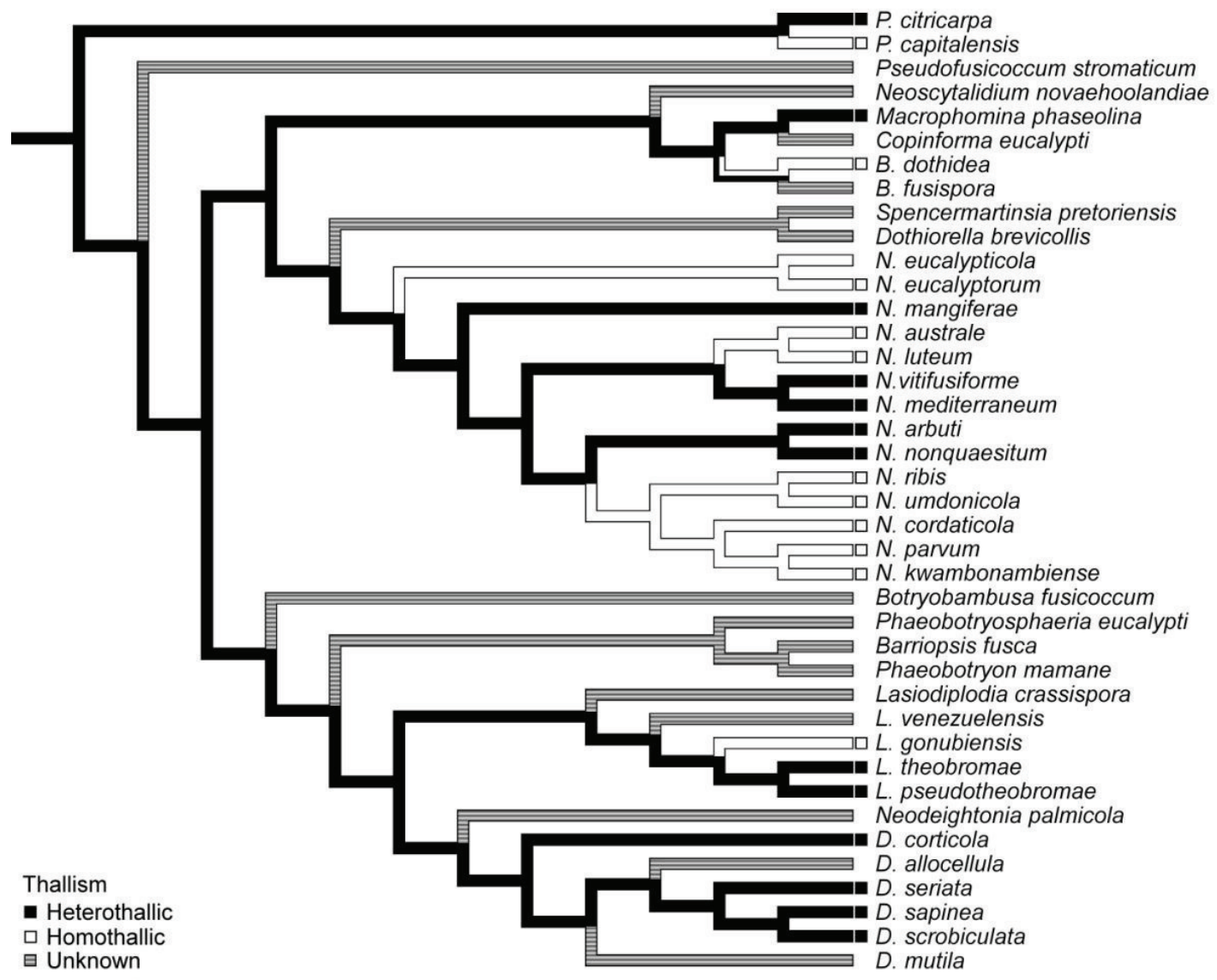

Fig. 4. Ancestral state reconstruction of sexual thallism of species of Botryosphaeriaceae. Two character states were mapped onto the phylogenetic tree: Heterothallism (solid) and homothallism (open). Grey lines denote undetermined states. 
idiomorphs was strongly conserved. The genomic position of the MAT1 locus was less conserved, with one or both of the Neofusicoccum MAT idiomorphs not in close proximity to the APN2-SAICARsyn gene cluster. Mating type gene fragments were present in the intergenic regions flanking the mating type genes in all heterothallic species and to a lesser extent in homothallic species. Phylogenetic analyses of the MAT1-1-1 and MAT1-2-1 genes produced phylogenetic trees congruent with the accepted phylogenetic topology for the Botryosphaeriaceae. Ancestral reconstruction suggested that heterothallism is the ancestral state for the Botryosphaeriaceae and that at least five transitions to homothallism have occurred.

\subsection{Mating type genes of Botryosphaeriaceae}

The mating type genes characterised in this study had low overall levels of nucleotide and amino acid sequence conservation. Despite the low sequence conservation among taxa in the Botryosphaeriaceae, the MATalpha_HMGbox domain of the MAT1-1-1 gene and the MATA_HMG-box domain of the MAT1-2-1 gene were conserved. This is consistent with the fact that mating type genes in the fungi have few differences within a species, but are highly divergent between species (Turgeon, 1998).

The MAT1-2-1 gene in $D$. sapinea and $D$. seriata has lost the intron that interrupts the MATA_HMG-box domain in other species. The amino acid sequences flanking the lost intron site remained intact in the MAT1-2-1 gene. This was consistent with the Poly-A primed mRNA derived intron loss model proposed for Cryptococcus (Sharpton et al., 2008). It is a strongly conserved trend that the MATalpha and the MAT_HMG-box domains are interrupted by introns in many ascomycetes (Arie et al., 2000; De Miccolis Angelini et al., 2016; Duong et al., 2013; Paoletti et al., 2005). No other instances of intron loss occuring within the fungal mating type genes have been reported. 
The MAT1-1-8 and MAT1-2-5 genes were consistently present in the Botryosphaeriaceae from the MAT1-1 and MAT1-2 idiomorphs, respectively. This is consistent with the situation previously reported in D. sapinea (Bihon et al., 2014) and N. parvum (Lopes et al., 2017). Both the MAT1-1-8 and MAT1-2-5 genes have also been reported in the Phyllostictaceae (Amorim et al., 2017; Wang et al., 2016). The MAT1-1-8 and MAT1-2-5 genes have not been encountered in the mating type idiomorphs in other orders of Dothideomycetes (Arie et al., 2000; Barve et al., 2003; Bennett et al., 2003; Cozijnsen and Howlett, 2003; Turgeon et al., 1993; Waalwijk et al., 2002).

\subsection{Organization of mating type loci}

Other than in the case of Neofusicoccum spp., the position of the mating type locus was conserved in species of Botryosphaeriaceae. The MAT1 locus was consistently flanked by the APN2-SAICARsyn gene cluster and the PIM gene in species from Botryosphaeria, Diplodia, Lasiodiplodia and Macrophomina. This finding was consistent with the position of the MAT1 locus in species of Phyllostictaceae, with the exception that the PIM gene has been incorporated into the idiomorphic region in P. citricarpa (Amorim et al., 2017; Wang et al., 2016).

The mating type idiomorphs did not occur in close proximity to one another in two Neofusicoccum species. Species in the Neofusicoccum parvum/N. ribis complex had neither mating type idiomorphs in close proximity to one another or to the APN2-SAICARsyn cluster. This was in agreement with the results of the previous study on N. parvum (Lopes et al., 2017). Neofusicoccum australe and N. luteum had the MAT1-2 idiomorph associated with the APN2-SAICARsyn cluster, but the MAT1-1 idiomorph did not occur in close proximity. The occurrence of the two mating types at unlinked regions is not without precedent in fungi and has been observed in Aspergillus nidulans (Galagan et al., 2005), Curvularia cymbopogonis (Yun et al., 1999) and Neosartorya fischeri (Rydholm et al., 2007). 
There was no evidence of mating type switching in the mating type loci in the species of Botryosphaeriaceae. Direct repeat-mediated DNA deletion of one or more mating type gene has been implicated in unidirectional mating type switching, i.e self-fertile to self-sterile conversion (Wilken et al., 2014; Xu et al., 2016; Yun et al., 2017). However, no such direct repeats were observed in the present study. Mating type switching has also never been reported for any species of Botryosphaeriaceae. It is thus unlikely that unidirectional mating type switching takes place in the Botryosphaeriaceae.

\subsection{Mating type gene fragments}

All heterothallic species of Botryosphaeriaceae in this study had gene fragments corresponding to either the MAT1-1-8 or MAT1-2-5 gene in the intergenic region flanking the mating type idiomorph. This has previously also been observed in $D$. sapinea (Bihon et al., 2014). Such gene fragments have often been observed at the MAT locus in other fungi (De Miccolis Angelini et al., 2016; Duong et al., 2013; King et al., 2015; Paoletti et al., 2005; Terhem et al., 2015; Tsui et al., 2013; Zaffarano et al., 2010). Invariably in all known cases, gene fragments correspond to a mating type gene of the opposite idiomorph.

The pattern of mating type gene fragments observed in the Botryosphaeriaceae can be explained by two hypothesis (Figure 5). One is that the mating type gene fragments are remnants of a deletion event (Figure 5a) involved in an ancestral shift from homothallism to heterothallism (Paoletti et al., 2005; Terhem et al., 2015). This hypothesis requires a homothallic ancestor and two independent deletion events. The other hypothesis interprets the mating type gene fragments as the result of unequal recombination (Figure 5b) occurring between idiomorphs in a heterothallic species (De Miccolis Angelini et al., 2016; Tsui et al., 2013; Zaffarano et al., 2010). This hypothesis requires a heterothallic ancestor and at least two unequal recombination events. Both these hypotheses would result in an idiomorphic locus with part of the mating type genes existing outside the idiomorphic region (Figure 5c). The sequence similarity of the gene fragments to the original genes would make continued 
a) Homothallic origin hypothesis

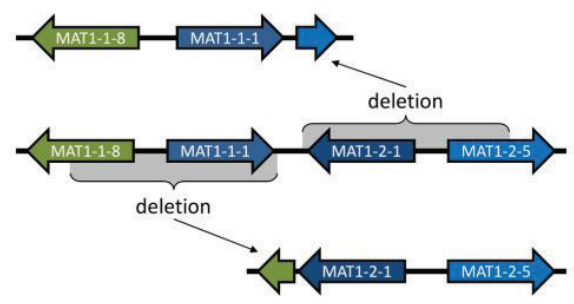

c) Predicted idiomorphic mating type locus

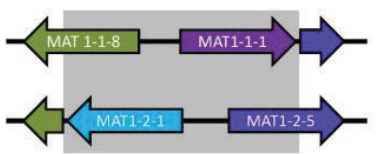

b) Heterothallic origin hypothesis

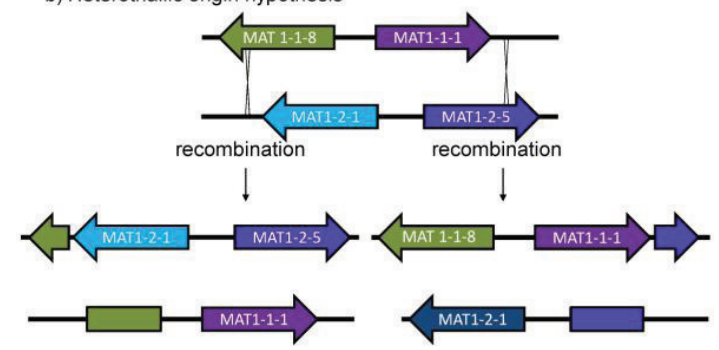

d) Example of observed idiomorphic mating type, i.e. Lasiodiplodia theobromea

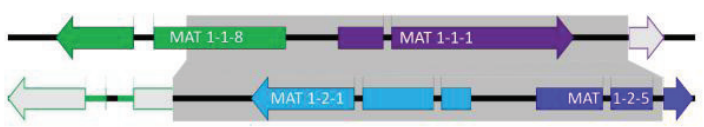

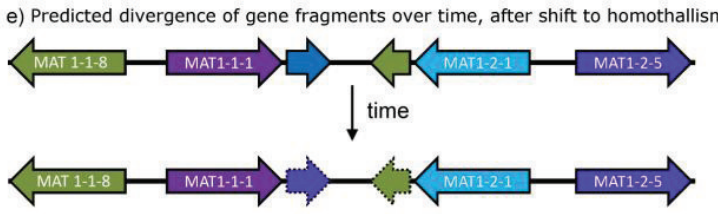

f) Example of observed homothallic mating type locus of Lasiodiplodia gonubiensis, containing a MAT 1-1-8 gene fragment, which sequence have diverged from the complete MAT 1-1-8 gene

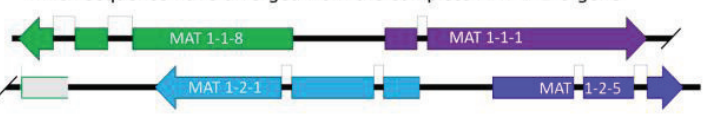

Fig. 5. Proposed models for the evolution of mating type in the Botryosphaeriaceae. Two mechanisms are hypothesized for the formation of heterothallic mating type idiomorphs containing partial gene fragments of either the MAT1-1-8 or MAT1-2-5 genes: (a) a primary homothallic, ancestral mating type locus that undergoes two independent deletions and (b) a heterothallic, ancestral mating type locus that undergoes two unequal crossing over/recombination events. (c) Both these mechanisms (in a and b) will result in a heterothallic mating type locus containing 3 ' gene fragments of the MAT1-1-8 or MAT1-2-5 genes at the MAT1-2 and MAT1-1 idiomorph. Sequence similarity between the MAT1-1-8/MAT1-2-5 genes and their fragments on the opposite idiomorph will permit homologous recombination within mating type genes and so reduce the effective size of the idiomorphic region (indicated by a grey block). Mating type gene fragments will maintain their sequence similarity to the complete MAT1-1-8 or MAT1-2-5 as long as recombination occurs between them. (d) An example of a heterothallic mating type locus with idiomorphic region not containing the $3^{\prime}$ ends of the MAT1-1-8 and MAT1-2-5 genes is shown, i.e. Lasiodiplodia theobromae. (e) If a subsequent heterothallic to homothallic conversion occurs both or one or none of the mating type gene fragments may be present. In this case the mating type gene fragments will no longer be maintained by recombination and will accumulate mutations that will reduce their homology to the complete genes over time, for example (f) the MAT1-1-8 fragment in Lasiodiplodia gonubiensis. 
recombination possible and prevent the two sequences from diverging in heterothallic species.

Mating type gene fragments occurred in some homothallic species of Botryosphaeriaceae, but with less sequence conservation to the complete gene than seen in heterothallic species. This can be interpreted as evidence of a heterothallic to homothallic transition. Such gene fragments would have had to exist prior to the transition to homothallism. Once both idiomorphs had become established at different positions in a genome, recombination between the fragments and complete genes would become much less likely. A reduction in recombination between mating type gene fragments and mating genes would allow mutations to accumulate and the sequences to diverge (Figure 6e). Mating type gene fragments have not previously been reported from homothallic fungi (Debuchy and Turgeon, 2006; Galagan et al., 2005).

\subsection{Phylogeny of mating type genes and ancestral reconstruction of thallism}

Both the MAT1-1-1 and MAT1-2-1 phylogenies were congruent with one another and with the accepted multigene phylogeny of the Botryosphaeriaceae (Slippers et al., 2013). This was consistent with the finding from other studies suggesting that phylogenies of mating type genes are generally consistent with those of other genes (Duong et al., 2013; Turgeon, 1998; Waalwijk et al., 2002; Yokoyama et al., 2006).

Ancestral state reconstruction suggested that heterothallism is the ancestral state in the Botryosphaeriales and that multiple, independent shifts to homothallism have occurred. Similarly, studies on numerous taxa of ascomycetes have also indicated that shifts from heterothallism to homothallism are common (Gioti et al., 2012; Inderbitzin et al., 2005; Nygren et al., 2011; Yokoyama et al., 2006; Yun et al., 1999). In contrast, there are no studies unambiguously showing a transition from homothallism to heterothallism. This is 
supported by population genetic models predicting that it is unlikely for heterothallism to become established in a homothallic population (Nauta and Hoekstra, 1992).

\subsection{Mating type markers}

Mating type markers that can be applied in many species and other populations of Botryosphaeriaceae were developed. Primers capable of amplifying the mating type genes of spesific species in Botryosphaeria, Diplodia and Lasiodiplodia were designed. Additionally the Lasiodiplodia mating type primers could also amplify the mating type genes of other Lasiodiplodia spp. and even some Diplodia spp. These primers will supplement the primers previously created for D. sapinea (Bihon et al., 2014) and Neofusicoccum spp. (Lopes et al., 2017). Mating type gene markers are immensly valuable population genetic tools for studying the presence or absence of sexual reproduction in plant pathogenic fungi (Bihon et al., 2014; Groenewald et al., 2006; Paoletti et al., 2005). Primer sets that allow amplification in a wide array of species are thus very valuable.

\section{Conclusions}

This study is the first to characterize and compare the MAT1 loci of species across many genera of the Botryosphaeriaceae. It illustrates the inherent variability in the DNA sequence of mating type genes, but also the organizational conformity within and outside the mating type regions in most species of Botryosphaeriaceae. The ubiquitous presence of mating type gene fragments outside the idiomorphic regions in heterothallic species emphasises the role of unequal crossing over. Their presence inside idiomorphic regions in homothallic species adds evidence to support multiple independent shifts from heterothallism. The application of the mating type markers developed in this and other studies will add valuable tools to characterize the population biology in the species of Botryosphaeriaceae. Together these data provide a foundation for future studies on the biology and evolution of species in this family. 


\section{Acknowledgements}

We are grateful to the University of Pretoria, The Department of Science and Technology (DST)/National Research Foundation (NRF) Centre of Excellence in Tree Health Biotechnology and members of the Tree Protection Cooperative Program for financial support of this study. We thank Prof. Ana Cristina Esteves for permitting us to use the genome data of $D$. corticola, prior to its publication. We also thank Dr. Tuan Duong for his critical comments on this manuscript.

\section{References}

Amorim, R., et al., 2017. MAT gene idiomorphs suggest a heterothallic sexual cycle in the citrus pathogen Phyllosticta citricarpa. Eur. J. Plant Pathol. 147, 325-337.

Arie, T., et al., 2000. Mating-type genes from asexual phytopathogenic ascomycetes Fusarium oxysporum and Alternaria alternata. Mol. Plant-Microbe Interact. 13, 13301339.

Barve, M. P., et al., 2003. Cloning and characterization of the mating type (MAT) locus from Ascochyta rabiei (teleomorph: Didymella rabiei) and a MAT phylogeny of legumeassociated Ascochyta spp. Fungal Genet. Biol. 39, 151-167.

Bennett, R. S., et al., 2003. Identity and conservation of mating type genes in geographically diverse isolates of Phaeosphaeria nodorum. Fungal Genet. Biol. 40, 25-37.

Bihon, W., et al., 2012a. High levels of genetic diversity and cryptic recombination is widespread in introduced Diplodia pinea populations. Australas. Plant Pathol. 41, 4146.

Bihon, W., et al., 2012b. Diverse sources of infection and cryptic recombination revealed in South African Diplodia pinea populations. Fungal Biol. 116, 112-120.

Bihon, W., et al., 2014. MAT gene idiomorphs suggest a heterothallic sexual cycle in a predominantly asexual and important pine pathogen. Fungal Genet. Biol. 62, 55-61.

Billiard, S., et al., 2012. Sex, outcrossing and mating types: unsolved questions in fungi and beyond. J. Evol. Biol. 25, 1020-1038. 
Blanco-Ulate, B., et al., 2013. Draft genome sequence of Neofusicoccum parvum isolate UCR-NP2, a fungal vascular pathogen associated with grapevine cankers. Genome announcements. 1, e00339-13.

Bolger, A. M., et al., 2014. Trimmomatic: a flexible trimmer for Illumina sequence data. Bioinformatics. btu170.

Butler, G., 2010. Fungal sex and pathogenesis. Clin. Microbiol. Rev. 23, 140-159.

Camacho, C., et al., 2009. BLAST+: architecture and applications. BMC Bioinformatics. 10, 421.

Cozijnsen, A. J., Howlett, B. J., 2003. Characterisation of the mating-type locus of the plant pathogenic ascomycete Leptosphaeria maculans. Curr. Genet. 43, 351-357.

De Miccolis Angelini, R. M., et al., 2016. Molecular analysis of the mating type (MAT1) locus in strains of the heterothallic ascomycete Botrytis cinerea. Plant Pathology. 65, $1321-1332$.

Debuchy, R., Turgeon, B. G., Mating-type structure, evolution, and function in Euascomycetes. Growth, Differentiation and Sexuality. Springer, 2006, pp. 293-323.

Duong, T. A., et al., 2013. Characterization of the mating-type genes in Leptographium procerum and Leptographium profanum. Fungal Biol. 117, 411-421.

Galagan, J. E., et al., 2005. Sequencing of Aspergillus nidulans and comparative analysisvith $A$. fumigatus and $A$. oryzae. Nature. 438, 1105-1115.

Gioti, A., et al., 2012. Unidirectional evolutionary transitions in fungal mating systems and the role of transposable elements. Mol. Biol. Evol. 29, 3215-3226.

Gladman, S., Seemann, T., 2012. VelvetOptimiser. Victorian Bioinformatics Consortium, Clayton, Australia: http://bioinformatics.net.au/software.velvetoptimiser.shtml.

Groenewald, M., et al., 2006. Mating type gene analysis in apparently asexual Cercospora species is suggestive of cryptic sex. Fungal Genet. Biol. 43, 813-825.

Idnurm, A., 2011. Sex and speciation: the paradox that non-recombining DNA promotes recombination. Fungal Biology Reviews. 25, 121-127. 
Inderbitzin, P., et al., 2005. Lateral transfer of mating system in Stemphylium. Proc. Natl. Acad. Sci. U. S. A. 102, 11390-11395.

Islam, M. S., et al., 2012. Tools to kill: genome of one of the most destructive plant pathogenic fungi Macrophomina phaseolina. BMC Genomics. 13, 493.

Katoh, K., Standley, D. M., 2013. MAFFT multiple sequence alignment software version 7: improvements in performance and usability. Mol. Biol. Evol. 30, 772-780.

King, K. M., et al., 2015. Differences in MAT gene distribution and expression between Rhynchosporium species on grasses. Plant Pathology. 64, 344-354.

Lopes, A., et al., 2017. Mating type genes in the genus Neofusicoccum: mating strategies and usefulness in species delimitation. Fungal Biol. 121, 394-404.

Liu, Z., et al., 2016. Draft genome sequence of Botryosphaeria dothidea, the pathogen of apple ring rot. Genome announcements. 4, e01142-16.

Maddison, W. P., Maddison, D. R., 2016. Mesquite: a modular system for evolutionary analysis V3.10. http://mesquiteproject.org.

Marchler-Bauer, A., et al., 2014. CDD: NCBI's conserved domain database. Nucleic Acids Res., gku1221.

Marsberg, A., et al., 2016. Botryosphaeria dothidea: a latent pathogen of global importance to woody plant health. Mol. Plant Pathol. 18, 477-488.

Massonnet, M., et al., 2016. Condition-dependent co-regulation of genomic clusters of virulence factors in the grapevine trunk pathogen Neofusicoccum parvum. Mol. Plant Pathol. DOI: 10.1111/mpp.12491.

Möller, E. M., et al., 1992. A simple and efficient protocol for isolation of high molecular weight DNA from filamentous fungi, fruit bodies, and infected plant tissues. Nucleic Acids Res. 20, 6115.

Nauta, M. J., Hoekstra, R. F., 1992. Evolution of reproductive systems in filamentous ascomycetes. I. Evolution of mating types. Heredity. 68, 405-410.

Ni, M., et al., 2011. Sex in fungi. Annu. Rev. Genet. 45, 405-430. 
Nygren, K., et al., 2011. A comprehensive phylogeny of Neurospora reveals a link between reproductive mode and molecular evolution in fungi. Mol. Phylogenet. Evol. 59, 649663.

Paoletti, M., et al., 2005. Evidence for sexuality in the opportunistic fungal pathogen Aspergillus fumigatus. Curr. Biol. 15, 1242-1248.

Pöggeler, S., et al., 1997. Mating-type genes from the homothallic fungus Sordaria macrospora are functionally expressed in a heterothallic ascomycete. Genetics. 147, 567-580.

Phillips, A. J. L., et al., 2013. The Botryosphaeriaceae: genera and species known from culture. Stud. Mycol. 76, 51-167.

Rambaut, A., Drummond, A., 2003. Tracer: a program for analysing results from Bayesian MCMC programs such as BEAST \& MrBayes. University of Edinburgh, UK.

Robert-Siegwald, G., et al., 2017. Draft Genome Sequence of Diplodia seriata F98. 1, a Fungal Species Involved in Grapevine Trunk Diseases. Genome announcements. 5, e00061-17.

Ronquist, F., Huelsenbeck, J. P., 2003. MrBayes 3: Bayesian phylogenetic inference under mixed models. Bioinformatics. 19, 1572-1574.

Rozen, S., Skaletsky, H., 1999. Primer3 on the WWW for general users and for biologist programmers. Bioinformatics methods and protocols. 365-386.

Rydholm, C., et al., 2007. DNA sequence characterization and molecular evolution of MAT1 and MAT2 mating-type loci of the self-compatible ascomycete mold Neosartorya fischeri. Eukaryot. Cell. 6, 868-874.

Sharpton, T. J., et al., 2008. Mechanisms of intron gain and loss in Cryptococcus. Genome biology. 9, R24.

Slippers, B., et al., 2013. Phylogenetic lineages in the Botryosphaeriales: a systematic and evolutionary framework. Stud. Mycol. 76, 31-49.

Slippers, B., et al., 2017. Diversity in the Botryosphaeriales: Looking back, looking forward. Fungal Biol. 
Slippers, B., Wingfield, M. J., 2007. Botryosphaeriaceae as endophytes and latent pathogens of woody plants: diversity, ecology and impact. Fungal Biology Reviews. 21, 90-106.

Stamatakis, A., 2014. RAxML version 8: a tool for phylogenetic analysis and post-analysis of large phylogenies. Bioinformatics. 30, 1312-1313.

Sullivan, M. J., et al., 2011. Easyfig: a genome comparison visualizer. Bioinformatics. 27, 1009-1010.

Terhem, R. B., et al., 2015. Mating type and sexual fruiting body of Botrytis elliptica, the causal agent of fire blight in lily. Eur. J. Plant Pathol. 142, 615-624.

Tsui, C. K. M., et al., 2013. Unequal recombination and evolution of the mating-type (MAT) loci in the pathogenic fungus Grosmannia clavigera and relatives. G3: Genes| Genomes| Genetics. 3, 465-480.

Turgeon, B. G., 1998. Application of mating type gene technology to problems in fungal biology. Annu. Rev. Phytopathol. 36, 115-137.

Turgeon, B. G., et al., 1993. Cloning and analysis of the mating type genes from Cochliobolus heterostrophus. Molecular and General Genetics MGG. 238, 270-284.

Turgeon, B. G., Yoder, O. C., 2000. Proposed nomenclature for mating type genes of filamentous ascomycetes. Fungal Genet. Biol. 31, 1-5.

van der Nest, M. A., et al., 2014. Draft genome sequences of Diplodia sapinea, Ceratocystis manginecans, and Ceratocystis moniliformis. IMA Fungus. 5, 135-140.

Waalwijk, C., et al., 2002. Isolation and characterization of the mating-type idiomorphs

from the wheat septoria leaf blotch fungus Mycosphaerella graminicola. Fungal Genet. Biol. 35, 277-286.

Wang, N.-Y., et al., 2016. Mating type and simple sequence repeat markers indicate a clonal population of Phyllosticta citricarpa in Florida. Phytopathology. 106, 1300-1310.

Wilken, P. M., et al., 2014. DNA loss at the Ceratocystis fimbriata mating locus results in self-sterility. PLoS ONE. 9, e92180. 
Wilken, P. M., et al., 2017. Which MAT gene? Pezizomycotina (Ascomycota) mating-type gene nomenclature reconsidered. Fungal Biology Reviews. 31, 199-211.

Wilson, A. M., et al., 2015. Homothallism: an umbrella term for describing diverse sexual behaviours. IMA Fungus. 6, 207-214.

Wingfield, B. D., et al., 2015. Draft genome sequences of Chrysoporthe austroafricana, Diplodia scrobiculata, Fusarium nygamai, Leptographium lundbergii, Limonomyces culmigenus, Stagonosporopsis tanaceti, and Thielaviopsis punctulata. IMA Fungus. 6, 233-248.

Xu, L., et al., 2016. Direct repeat-mediated DNA deletion of the mating type MAT1-2 genes results in unidirectional mating type switching in Sclerotinia trifoliorum. Scientific reports. 6, 27083.

Yan, J. Y., et al., 2017. Comparative genome and transcriptome analyses reveal adaptations to opportunistic infections in woody plant degrading pathogens of Botryosphaeriaceae. DNA Research. dsx040.

Yokoyama, E., et al., 2006. Phylogenetic and structural analyses of the mating-type loci in Clavicipitaceae. FEMS Microbiol. Lett. 264, 182-191.

Yun, S.-H., et al., 2000. Molecular organization of mating type loci in heterothallic, homothallic, and asexual Gibberella/Fusarium species. Fungal Genet. Biol. 31, 7-20.

Yun, S.-H., et al., 1999. Evolution of the fungal self-fertile reproductive life style from selfsterile ancestors. Proceedings of the National Academy of Sciences. 96, 5592-5597.

Yun, S.-H., et al., 2017. Self-fertility in Chromocrea spinulosa is a consequence of direct repeat-mediated loss of MAT1-2, subsequent imbalance of nuclei differing in mating type, and recognition between unlike nuclei in a common cytoplasm. PLOS Genetics. 13, e1006981.

Zaffarano, P. L., et al., 2010. Characterization of the mating type (MAT) locus in the Phialocephala fortinii sl-Acephala applanata species complex. Fungal Genet. Biol. $47,761-772$. 
Zerbino, D. R., Birney, E., 2008. Velvet: algorithms for de novo short read assembly using de Bruijn graphs. Genome Res. 18, 821-829. 


\section{Appendix A. Supplementary material}

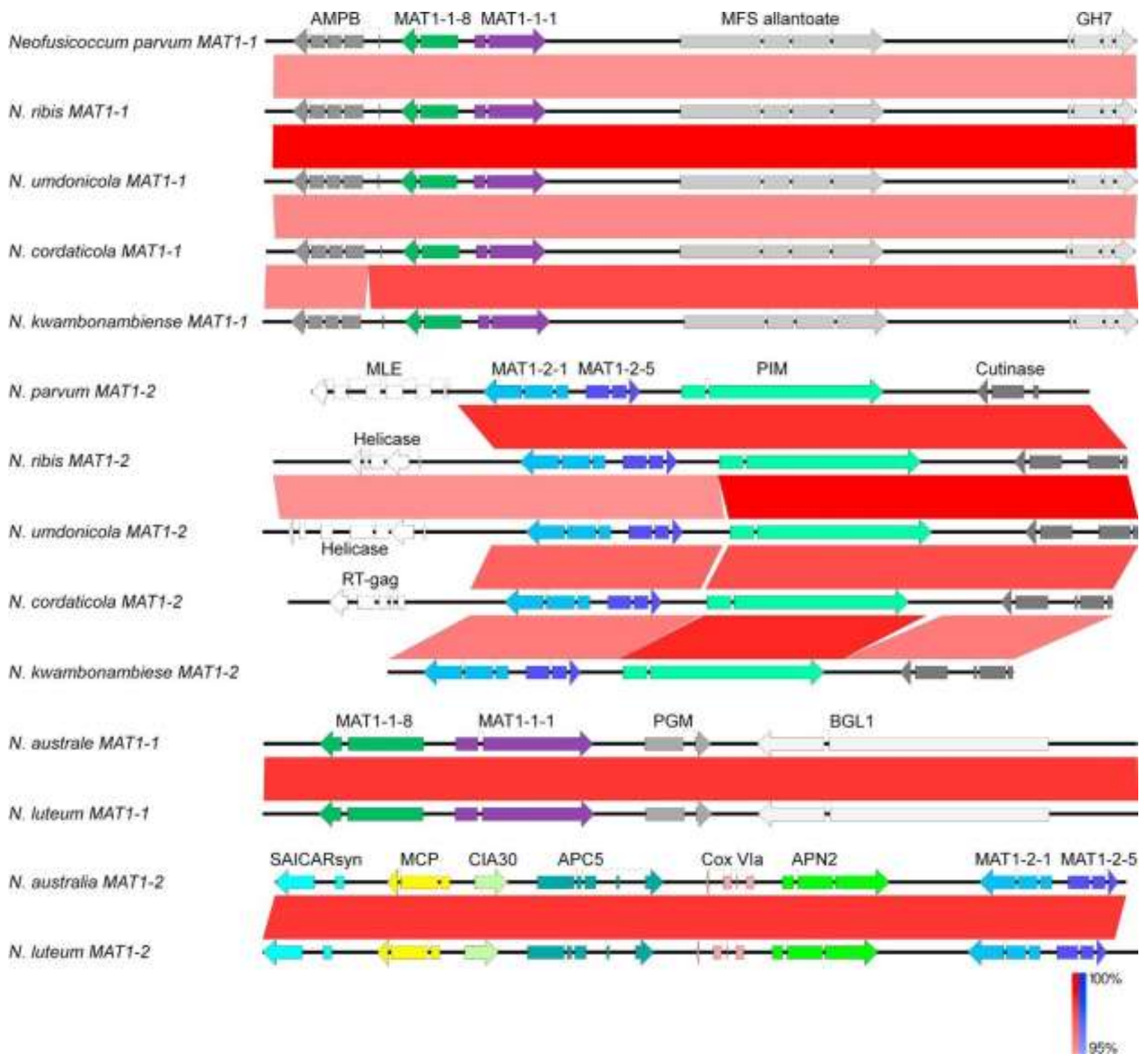

Supplementary figure 1. 


\begin{tabular}{|c|c|c|c|c|c|c|c|c|c|c|c|c|}
\hline \multirow{2}{*}{\multicolumn{4}{|c|}{$\begin{array}{l}\text { Supplementary Table: Coding sequence size, intron size and start } \\
\qquad M A T 1-1-1\end{array}$}} & \multirow{2}{*}{\multicolumn{3}{|c|}{ MAT 1-1-8 }} & \multirow{2}{*}{\multicolumn{3}{|c|}{$\begin{array}{l}\text { Botryosphaerlaceae } \\
\text { MAT 1-2-1 }\end{array}$}} & & & \\
\hline & & & & & & & & & & \multicolumn{3}{|c|}{ MAT 1-2-5 } \\
\hline Species & CDS size & $\begin{array}{l}\text { Intron } \\
\text { size }\end{array}$ & $\begin{array}{l}\text { Intron start } \\
\text { position* }^{*}\end{array}$ & $\begin{array}{l}\text { CDS } \\
\text { size }\end{array}$ & $\begin{array}{l}\text { Intron } \\
\text { size }\end{array}$ & $\begin{array}{l}\text { Intron start } \\
\text { position }\end{array}$ & $\begin{array}{l}\text { CDS } \\
\text { size }\end{array}$ & $\begin{array}{l}\text { Intron } \\
\text { size }\end{array}$ & $\begin{array}{l}\text { Intron start } \\
\text { position }\end{array}$ & $\begin{array}{l}\text { CDS } \\
\text { size }\end{array}$ & $\begin{array}{l}\text { Intron } \\
\text { size }\end{array}$ & $\begin{array}{c}\text { Intron start } \\
\text { position }\end{array}$ \\
\hline Botryosphaeria dothidea & 1287 & 52 & 230 & 2124 & 71 & 854 & 1290 & 49,51 & 192,617 & 852 & 59,81 & 405,666 \\
\hline Diplodia corticola & 1497 & 49 & 302 & 1407 & 145 & 830 & & & & & & \\
\hline D. sapinea & 1335 & 48 & 263 & 1191 & 96 & 845 & 1170 & 49 & 189 & 900 & 49,67 & 432,753 \\
\hline D. scrobiculata & 1329 & 48 & 248 & 1191 & 96 & 845 & & & & & & \\
\hline D. seriata & 1344 & 48 & 262 & 1191 & 98 & 845 & 1165 & 49 & 189 & 900 & 49,67 & 432,753 \\
\hline Lasiodiplodia gonubiensis & 1449 & 51 & 287 & 1212 & 128,114 & 851,1155 & 1302 & 48,52 & 195,680 & 894 & 49,67 & 432,750 \\
\hline L. theobromae & 1473 & 49 & 296 & 1356 & 129 & 854 & 1320 & 48,52 & 195,701 & 897 & 49,67 & 432,753 \\
\hline L. pseudotheobromae & 1488 & 51 & 281 & 1353 & 128 & 851 & & & & & & \\
\hline Macrophomina phaseolina & 1266 & 125 & 230 & 1233 & 64 & 860 & 1377 & 49,51 & 192,714 & 876 & 58,65 & 396,739 \\
\hline Neofusicoccum australe & 1491 & 52 & 254 & 1098 & 73 & 848 & 1362 & 50,50 & 237,685 & 888 & 54,63 & 429,746 \\
\hline N. cordaticola & 1533,1512 & 52 & 254 & 1218 & 70 & 848 & 1470 & 50,50 & 228,805 & 888 & 52,63 & 429,744 \\
\hline N. kwambonambiense & 1584 & 52 & 254 & 1218 & 70 & 848 & 1470 & 50,50 & 228,805 & 888 & 52,63 & 429,744 \\
\hline N. luteum & 1512 & 52 & 254 & 1098 & 73 & 848 & 1362 & 50,50 & 237,685 & 888 & 54,63 & 429,746 \\
\hline N. parvum & 1575,1596 & 52 & 254 & 1218 & 70 & 848 & 1470 & 50,50 & 228,805 & 888 & 52,59 & 429,744 \\
\hline N. ribis & 1575 & 52 & 254 & 1218 & 71 & 848 & 1470 & 50,50 & 228,805 & 888 & 52,63 & 429,744 \\
\hline N. umdonicola & 1596 & 52 & 254 & 1218 & 71 & 848 & 1470 & 50,50 & 228,805 & 888 & 52,63 & 429,744 \\
\hline
\end{tabular}

* Intron start position measured in number of base pairs from the first base of the gene. 